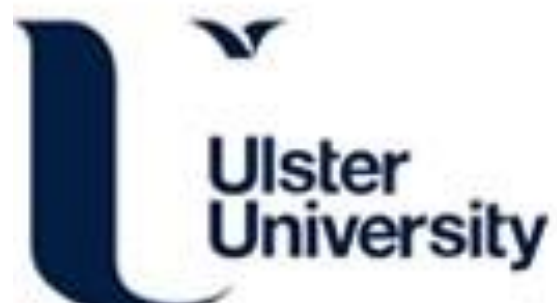

\section{Streptomyces from traditional medicine: sources of new innovations in antibiotic discovery}

Quinn, G., Banat, A., Abdelhameed, A. M., \& Banat, I. M. (2020). Streptomyces from traditional medicine: sources of new innovations in antibiotic discovery. Journal of Medical Microbiology, 69(8), 1040-1048. https://doi.org/10.1099/jmm.0.001232

Link to publication record in Ulster University Research Portal

\section{Published in:}

Journal of Medical Microbiology

Publication Status:

Published (in print/issue): 21/07/2020

DOI:

https://doi.org/10.1099/jmm.0.001232

\section{Document Version}

Publisher's PDF, also known as Version of record

\section{General rights}

Copyright for the publications made accessible via Ulster University's Research Portal is retained by the author(s) and / or other copyright owners and it is a condition of accessing these publications that users recognise and abide by the legal requirements associated with these rights.

\section{Take down policy}

The Research Portal is Ulster University's institutional repository that provides access to Ulster's research outputs. Every effort has been made to ensure that content in the Research Portal does not infringe any person's rights, or applicable UK laws. If you discover content in the Research Portal that you believe breaches copyright or violates any law, please contact pure-support@ulster.ac.uk. 


\title{
Streptomyces from traditional medicine: sources of new innovations in antibiotic discovery
}

\author{
Gerry A. Quinn 1,*, Aiya M. Banat², Alyaa M. Abdelhameed ${ }^{3}$ and Ibrahim M. Banat ${ }^{1}$
}

\begin{abstract}
Given the increased reporting of multi-resistant bacteria and the shortage of newly approved medicines, researchers have been looking towards extreme and unusual environments as a new source of antibiotics. Streptomyces currently provides many of the world's clinical antibiotics, so it comes as no surprise that these bacteria have recently been isolated from traditional medicine. Given the wide array of traditional medicines, it is hoped that these discoveries can provide the much sought after core structure diversity that will be required of a new generation of antibiotics. This review discusses the contribution of Streptomyces to antibiotics and the potential of newly discovered species in traditional medicine. We also explore how knowledge of traditional medicines can aid current initiatives in sourcing new and chemically diverse antibiotics.
\end{abstract}

\section{INTRODUCTION}

Streptomyces are the source of many of the world's antibiotics and in this respect they represent a very important bacterial genus [1]. They are present in almost all environments from deep sea to high mountains [2-4]. They are Gram-positive, filamentous, spore-forming bacteria that are members of the phylum Actinobacteria. Streptomyces diverged from their closest relative, Kitasatospora, approximately 382 million years ago in the late Devonian period, coinciding with the appearance of land vertebrates [5, 6]. Streptomyces are non-motile bacteria that spread by producing threadlike hyphae which penetrate surfaces in search of nutrients. When resources are limited, Streptomyces produce aerial hyphae that divide, producing spores that can resist unfavourable conditions and are easily dispersed to new environments or sources of nutrients [7].

During this growth phase Streptomyces produce secondary metabolites: compounds that are not strictly necessary for growth or reproduction, but can give the organism a competitive advantage [7]. These metabolites help the vegetative bacterial cells by sequestering metals such as iron (siderophores), protecting them from UV light (through pigmentation), inhibiting competitors (antibiotics) and also facilitating communication with other species [8]. This molecular diversity is possible in Streptomyces through their comparatively large genome, which can be quadruple the size of some other bacterial genomes [7]. In this review, we look at the contribution of Streptomyces to antimicrobial chemotherapy, new innovations in bioprospecting through the association of Streptomyces with traditional medicine and the application of this knowledge to antibiotic discovery.

\section{Antibiotics from Streptomyces}

The antibiotic streptomycin was discovered in 1943 by Albert Schatz, a PhD student of Selman Waksman, with help from others including Doris Ralston, Elizabeth Bugie and Christine Reilly [9]. During World War II, there was an urgent drive to find antibiotics that could fill the gap left by penicillin, which was ineffective against tuberculosis (TB) and some Gram-negative pathogens. Inspired by Fleming's discovery, Waksman instructed his $\mathrm{PhD}$ student to screen bacterial isolates against a highly virulent TB strain in the basement of his laboratory. It was here that Schatz discovered streptomycin from an isolate of Streptomyces griseus originating from heavily manured compost soil and another from a chicken gizzard [9]. Given the importance of such a discovery, the first vial of streptomycin, which Schatz presented to his mother, is still on display in the Smithsonian Institution [10]. Selman Waksman used his drug company connections to conduct the large-scale trials necessary to prove that streptomycin was effective against $\mathrm{TB}$, bubonic plague, typhoid fever and 
Table 1. Clinically and economically important bioactive molecules from Streptomyces species, including name, mode of action and source

\begin{tabular}{|c|c|c|c|}
\hline $\begin{array}{l}\text { Bioactive } \\
\text { molecule }\end{array}$ & Type & Species & Location /soil type \\
\hline Bialaphos & Herbicide & S. hygroscopicus & Easter Island, soil [74] \\
\hline Bleomycin & Anticancer & 'S. verticillus' & Soil, coal mine [75] \\
\hline Chloramphenicol & Antibiotic & S. venezuelae & Soil and compost [76] \\
\hline Cineromycin $\mathrm{A}+\mathrm{B}$ & $\begin{array}{l}\text { Inhibits adipocyte differentiation of 3T3-L1 cells } \\
\text { via Krüppel-like factors } 2 \text { and } 3\end{array}$ & S. cinerochromogenes & Tama Graveyard soil, Tokyo, Japan [77] \\
\hline Clavulanic acid & $\beta$-lactamase inhibitor & S. clavuligerus & South American soil sample [78] \\
\hline Clindamycin & Antibiotic & S. lincolnensis & Lincoln, NE, USA [79] \\
\hline+ & + & & \\
\hline lincomycin & Antibiotic for mycoplasmas and Actinomyces & & \\
\hline Daptomycin & Lipopeptide antibiotic & S. roseosporus & Mount Ararat, Turkey [80] \\
\hline Erythromycin & Antibiotic & S. erythraeus & Soil, Philippines [81] \\
\hline Fosfomycin & $\begin{array}{l}\text { Broad-spectrum antibiotic against urinary tract } \\
\text { infections }\end{array}$ & S. fradiae & Soil, Mount Montgo, Spain [82] \\
\hline Ivermectin & $\begin{array}{l}\text { Antiparasitic, anti-onchocerciasis and anti- } \\
\text { lymphatic filariasis }\end{array}$ & S. avermitilis & Japanese golf course [83] \\
\hline Kanamycin & Antibiotic & S. kanamyceticus & Soil, Nagano, Japan [84] \\
\hline Neomycin & Antibiotic & S. fradiae and 'S. albogriseus' & Soil $[85]$ \\
\hline Nystatin & Antifungal & S. noursei & Garden soil [86] \\
\hline Rapamycin & Antifungal, antitumour immunosuppressive & S. hygroscopicus & Easter Island, soil [87] \\
\hline $\begin{array}{l}\text { Saframycin }(\mathrm{s}) \mathrm{A} \text {, } \\
\mathrm{B}, \mathrm{C}, \mathrm{D} \text { and } \mathrm{E}\end{array}$ & Anticancer & S. lavendulae subsp. grasserius & Tama Graveyard, Tokyo, Japan [88] \\
\hline Streptomycin & Antibiotic against TB, cholera, bubonic plague & S. griseus & Compost manure, Rutgers Farm, New York, USA [12] \\
\hline Tetracycline & Antibiotic & S. aureofaciens and S. rimosus & $\begin{array}{l}\text { Timothy grassland, Sanborn Field, University of } \\
\text { Missouri, USA [89] }\end{array}$ \\
\hline Vancomycin & Antibiotic & $\begin{array}{l}\text { 'S. orientalis' (now named } \\
\text { Amycolatopsis orientalis) }\end{array}$ & Borneo dirt $[90]$ \\
\hline
\end{tabular}

cholera $[2,9,11,12]$. Waksman was credited with coining the term 'antibiotic' winning the Nobel Prize for Medicine in 1952 and patenting eight antibiotics [4], some of which are detailed in Table 1.

Up until the 1970s, it was still relatively easy to isolate new compounds from Streptomyces, but since 1985 only three new classes of antibiotics that have been discovered [13-15]. One of these compounds is platensimycin, a new class of antibiotic from Streptomyces platensis that selectively inhibits cellular lipid biosynthesis. This was discovered by the Merck group [13, 14].

Very recently, an antibiotic-producing strain of thermotolerant Streptomyces sp. TM32 was isolated from the rhizosphere of Curcuma longa L., a medicinal plant [16]. This is believed to be a new strain of Streptomyces sioyaensis that has strong antimicrobial activities against both human and plant pathogens, including an antibiotic-resistant pathogen, Staphylococcus haemolyticus MR-CoNS [16]. It may also serve as an emerging source for further discovery of valuable and novel bioactive compounds.

\section{Antibiotic mode of action}

There are a few common modes of action for Streptomyces antibiotics targeting cellular components of bacteria. The first discovered mechanism was the interference with bacterial protein synthesis by blocking ribosomal functional sites [17]. Tetracycline, streptomycin, kanamycin and gentamicin block protein synthesis by binding to the small ribosomal subunit (30S), whereas erythromycin, clindamycin and chloramphenicol target the large ribosomal subunit (50S). Ciprofloxacin and novobiocin interfere with bacterial DNA translation. Carbapenems, cephalosporins, vancomycin, fosfomycin, bacitracin and daptomycin, in comparison, interfere with the bacterial cell wall or cell-membrane integrity and synthesis $[18,19]$. 


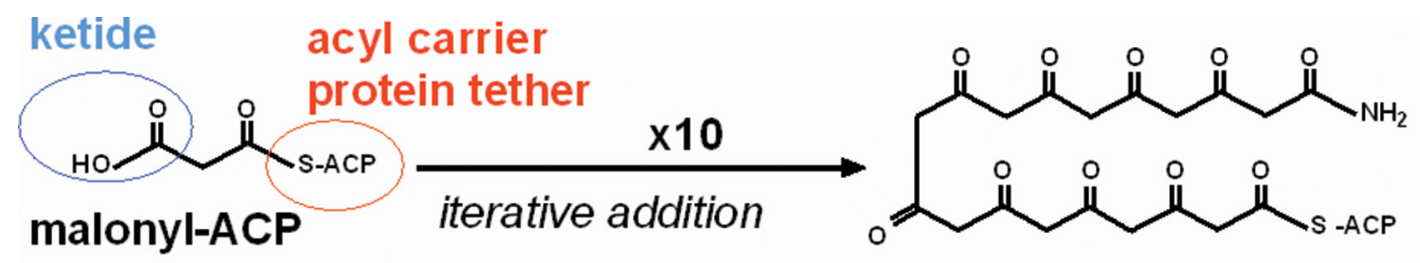

\section{8-Carbamoyl-3,5,7,9,11,13,15,17-octaoxo-octadecanoyl-[acp]}

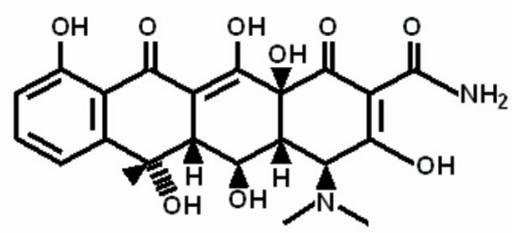

oxytetracycline

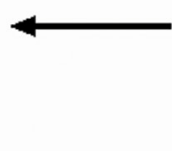

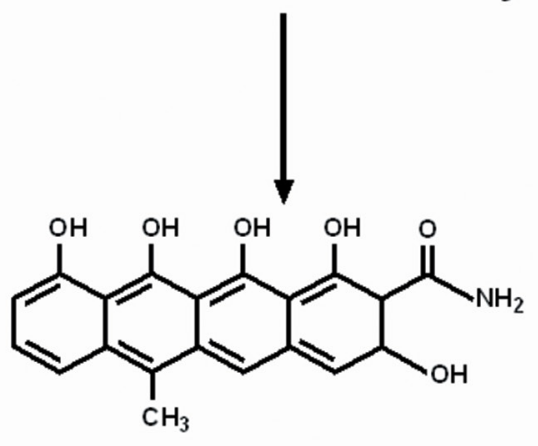

6-methylpretetramide

Fig. 1. Oxytetacyline synthesis by the PKS type II system: consecutive modules of the PKS type II enzyme catalyse the successive decarboxylative condensations of malonyl CoA, followed by modifications by transferases, oxygenases and cyclases, and additional modifications to produce oxytetracycline. Figure adapted from that of the Nomenclature Committee of the International Union of Biochemistry and Molecular Biology (NC-IUBMB) in consultation with the IUPAC-IUBMB Joint Commission on Biochemical Nomenclature (JCBN) [91].

\section{Antibiotic synthesis}

Streptomyces generally synthesize their antibiotics using large enzymatic complexes like polyketide synthases (PKSs), nonribosomal peptide synthases (NRPSs) or a combination of both. These large multienzyme complexes use many different domains to accomplish chemical modifications that can produce a wide range of antibiotics $[20,21]$.

In the PKS system, antibiotics typically begin as a ketide monomer attached to an acyl carrier protein. Construction of the antibiotic proceeds through a series of enzyme-mediated steps typically involving acyltransferases, ketidesynthases and other enzymes leading to the formation of the backbone of the polyketide antibiotic. The growing antibiotic can be subject to further modifications that might include cyclization, decarboxylation, dehydration, reduction and methylation [21] (Fig. 1).

Non-ribosomal peptide synthesis is carried out by large enzymatic complexes. These enzymes can be found in many types of bacteria and are organized in modules responsible for the addition of one amino acid at a time [20] (Fig. 2). NRPS peptides may also contain nonstandard amino acids such as diaminobutyric acid (Dab), and can be modified by glycosylation, amidation and halogenation amongst other processes [20].

\section{Discovery of Streptomyces in traditional medicine}

Traditional medicine containing antibiotics has been around and used in local remedies for millennia without knowledge of its active principles. One of the earliest connections between Streptomyces and traditional medicine is the Red Soil of Jordan, which has been used as a cure for skin infections for millennia [22]. More definitive connections have been found in Africa, where researchers discovered that some ancient Nubian bones ( 300 AD) contained tetracycline. This was traced back to a local beer drunk by the Nubians containing oats that had Streptomyces growing on them [23].

Following the UK Medical Act (1852), traditional medical practitioners who were not officially recognized were prohibited from claiming to cure illnesses. This saw traditional medicine in the UK fade into the background apart from in remote rural areas [24]. It would then be another 80 years before antibiotics made an official appearance in clinical practice with the discovery of penicillin [25].

\section{Streptomyces from traditional medicinal plants}

One of the inspirations for research into traditional medicine may have come from Geoffrey Cordell, who devised a series of systematic searches of plant metabolites for anticancer medicines. This included an ethno-medical approach, which evaluated written or historical evidence from traditional medicinal 


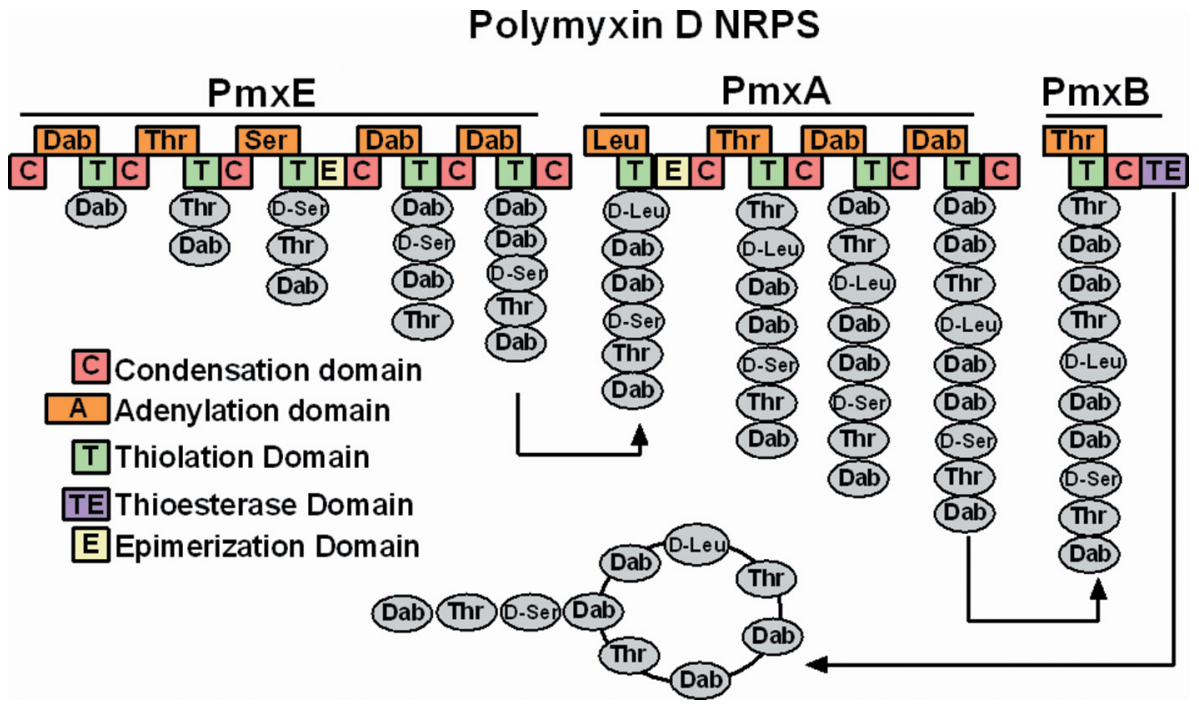

Fig. 2. NRPS system for polymyxin from Paenibacillus polymyxa. The NRPS enzyme is composed of many modules that contain subunits (boxes) that help to attach amino acids. The thioesterase domain (TE) is responsible for cyclizing and releasing the peptide at the end of synthesis. Figure reproduced by kind permission of Dr T. Velkov [92].

practice [26]. Since then, many Streptomyces have been isolated from traditional plant medicines, especially in areas of low nutrient availability or extreme physiological conditions [27, 28]. These Streptomyces can exist as endophytes that live at least a part of their life cycle inside plant tissues without causing damage, or epiphytes that live on the outside of the plants $[29,30]$. Proteobacteria and Actinobacteria have been reported as the most frequent endophytic species [31]. Many studies focused on the largest areas of traditional medicine such as China and India, but there have also been discoveries in South America and Africa [32, 33] (Table 2).

\section{Streptomyces-linked traditional medicine from invertebrates}

Invertebrates have many associations with Streptomyces and traditional medicine [34-36]. In northern India, a paste made from crushed black ants (Bothroponera rufipes) has been reported to be used to treat scabies, wounds and boils [37]. Additionally, ground ants mixed with water are used to relieve toothaches [34]. What makes these remedies so interesting is that Streptomyces are associated with certain parts of the ant's exoskeleton [38]. In some cases, the ants

Table 2. Streptomyces spp. isolated from traditional medical plants, including source, type and location

\begin{tabular}{|c|c|c|c|c|}
\hline Plant & Antibiotic & Location & Streptomyces & Reference \\
\hline $\begin{array}{l}\text { Lychnophora ericoides } \\
\text { Mart. }\end{array}$ & $\begin{array}{l}\text { 2,3-dihydro-2,2-dimethyl- } 4(1 \mathrm{H}) \text { - } \\
\text { quinazolinone, } \\
\text { nocardamine }\end{array}$ & Brazil & Effective against Trypanosoma cruzi & [64] \\
\hline $\begin{array}{l}\text { Achnatherum inebrians, } \\
\text { Drunken Horse Grass }\end{array}$ & Whole extracts & $\begin{array}{l}\text { Mountain Xinjiang, } \\
\text { China }\end{array}$ & $\begin{array}{l}\text { Streptomyces albus } \\
\text { effective against Aphis gossypii }\end{array}$ & [94] \\
\hline $\begin{array}{l}\text { Dracaena } \\
\text { cochinchinensis Lour., } \\
\text { Dragons blood }\end{array}$ & $\begin{array}{l}\text { Actinomycin-D, } \\
\text { novel SPE-B11.8 }\end{array}$ & $\begin{array}{l}\text { Ninh Binh province, } \\
\text { Vietnam }\end{array}$ & $\begin{array}{l}\text { Streptomyces sp. HUST012, } \\
\text { effective against MRSA, MRSE, Escherichia coli } \\
\text { and Klebsiella pneumoniae }\end{array}$ & [95] \\
\hline
\end{tabular}

Staphylococcus epidermidis (MRSE), usually harmless skin commensal that can cause difficult-to-treat multi-resistant infections. 


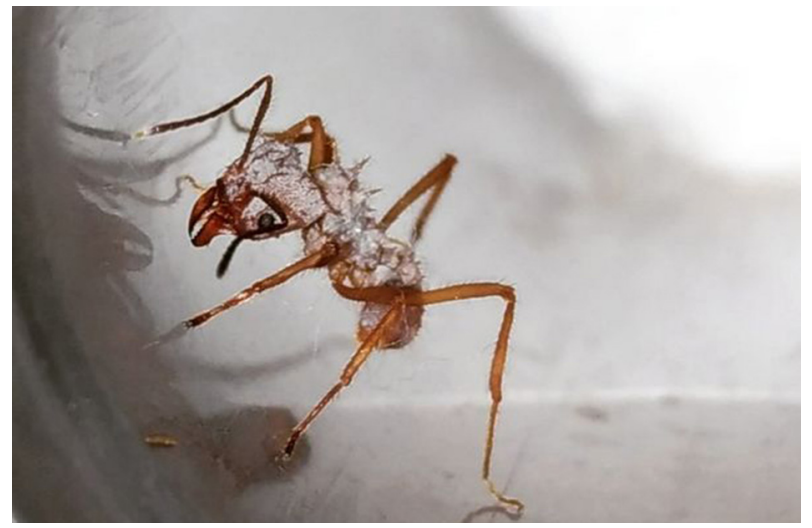

Fig. 3. A leafcutter ant (Acromyrmex) covered in Pseudonocardia. Photograph by João Pedro Sá Medeiros (Antwiki - https://www.antwiki. org/wiki/Acromyrmex) [40].

rub their legs over these patches (of Streptomyces) and then onto areas where they farm fungi $[38,39]$. A prime example of this is leafcutter ants (Acromyrmex), which use a species of Actinomycete known as Pseudonocardia as a defence against invasive parasites in their fungal gardens [40] (Fig. 3).

It has also been found that African Tetraponera penzigi ants living in hollows inside Acacia trees called domatia harbour Streptomyces formicae, which produces potent antibiotics known as formicamycins (Fig. 4). These antibiotics have been reported to have inhibitory effects against meticillin-resistant Staphylococcus aureus (MRSA) and vancomycin-resistant enterococci [38].

The interactions between Streptomyces and ants has prompted researchers to examine other symbiotic relationships in invertebrates. For instance, it was recently discovered that mud dauber wasps had an association with Streptomyces that produce a novel polyunsaturated and polyoxygenated

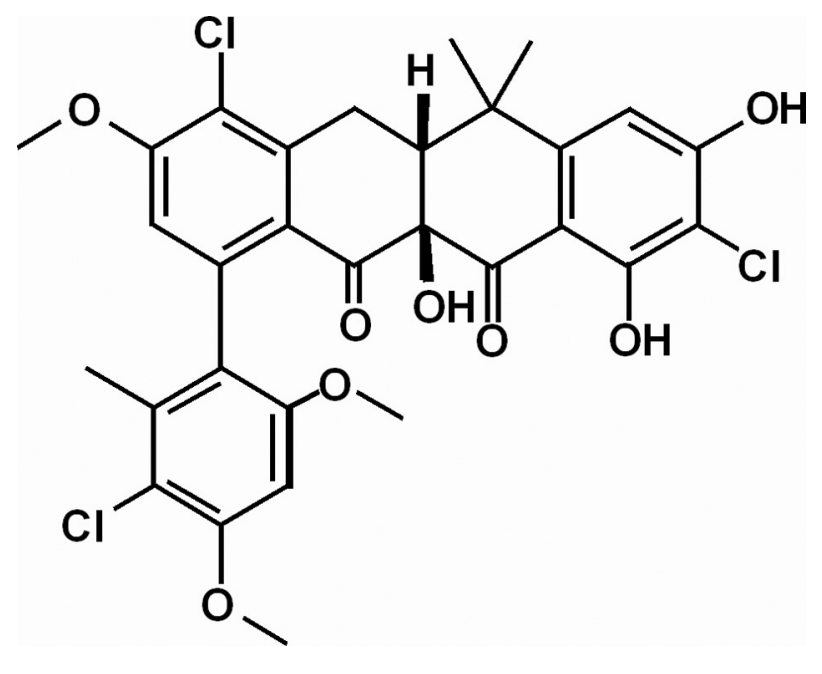

Fig. 4. Formicamycin E. Adapted from [38]. macrocyclic lactam (sceliphrolactam) which is an antifungal agent [41].

\section{Sponges}

Sponges have a very long history in traditional medicine [42], although their symbiotic relationships with antibioticproducing Streptomyces has only recently been discovered [43]. It is thought that Streptomyces from the marine environment can offer a potentially novel source of antimicrobial compounds $[43,44]$. Chinese researchers recently reported the isolation of Streptomyces tirandamycinicus sp. nov., from a marine sponge with antibacterial potential against Streptococcus agalactiae [45]. Other researchers have isolated new compounds from Streptomyces associated with marine sponges in the Vietnam Sea, some of which are completely novel compounds active against both Gram-positive and Gram-negative bacteria and Mycobacterium tuberculosis [46]. Under certain conditions, these new bioactive compounds can also inhibit bacterial biofilm formation [47].

\section{Antibiotics from caves}

Over the last few decades, karst and cave environments have become popular areas for bioprospecting of antimicrobial Streptomyces [48, 49]. Many of these areas are often associated with traditional medicine. Ancient texts suggest that a milky white exudate covering the surfaces of some caves called 'moonmilk' can heal multiple ailments [50]. Digging deeper, research has shown that moonmilk contains an abundance of Streptomyces that have antibacterial activity against a wide range of bacteria and fungi $[49,50]$, and display strong growth suppression against multi-resistant Rasamsonia argillacea, a causative agent of invasive mycosis in cystic fibrosis and chronic granulomatous diseases [50]. Similar studies from the Hampoeil cave (dolomite with limestone) in Iran, linked to Palaeolithic habitation, revealed many antimicrobialproducing Streptomyces, as well as other species [51].

\section{Streptomyces from traditional soil-based medicine}

The majority of modern antibiotics are derived from soilbased Streptomyces, so it is no surprise to discover that this media also features prominently in traditional medicine $[22,52]$. Unlike Streptomyces discovered from the golden age of antibiotic discovery in the mid-20th century, traditional medicine soils are specific in their locations such as the Boho clay, or in their type such as glacial clay from Canada $[52,53]$. Clay, which has long been thought to be therapeutic in itself, is also home to a diverse array of Streptomyces [22, 52-54]. Traditional glacial clay from Kisameet Bay in Canada has been used for millennia by the Heiltsuk people against skin infections [52]. When tested under laboratory conditions, this soil was shown to inhibit the growth of all six ESKAPE pathogens (Enterococcus faecium, Staphylococcus aureus, Klebsiella pneumoniae, Acinetobacter baumannii, Pseudomonas aeruginosa and Enterobacter spp.) [52]. On the other side of the Atlantic, researchers in Northern Ireland isolated a new species of Streptomyces from an ancient soil remedy in a region known as Boho, West Fermanagh [53]. 


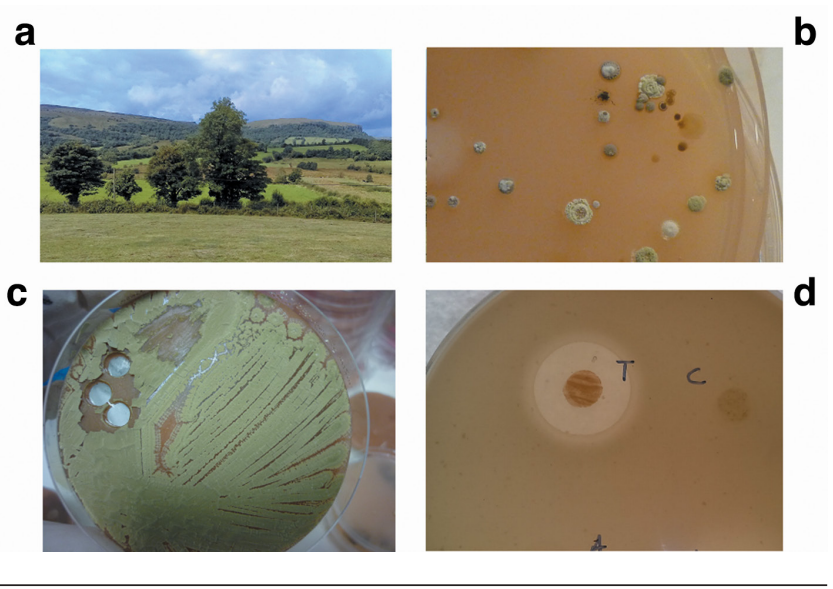

Fig. 5. Streptomyces from a traditional soil cure in the West Fermanagh Scarplands (a) was cultivated on selective isolation agar (b) yielding Streptomyces sp. myrophorea (c), which inhibited MRSA, as evidenced by a clear zone of inhibition (d).

This alkaline soil, lying on top of carboniferous limestone, contained a new species, Streptomyces sp. myrophorea, that inhibited several strains of MRSA, vancomycin-resistant Enterococcus, carbapenem-resistant Acinetobacter baumannii and Pseudomonas aeruginosa [53] (Fig. 5).

\section{Lessons from traditional medicine}

How can associations between Streptomyces and traditional medical preparations help the search for new antibiotics?

\section{Silent antibiotic clusters}

After whole-genome sequencing Streptomyces coelicolor A3(2), researchers discovered that instead of the usual two or three antibiotics detected under laboratory conditions, the genome encoded the potential to synthesize ten times this number [55]. This clearly means that there were other antibiotic-synthesis clusters that were not always expressed and are, therefore, now known as 'silent clusters' [56]. In recent years, it has been found that stress or extreme environmental triggers can stimulate these silent clusters to produce antibiotics [57-59]. Sometimes referred to as the 'one strain, many compounds phenomenon' (OSMAC) [60].

Many traditional medicines containing Streptomyces are associated with extreme environments typically low in nutrients, such as deserts, high altitudes, salt plains or cold areas where these bacteria form symbiotic associations with indigenous flora $[30,61]$. These harsh conditions can also be used in the laboratory to awaken some silent gene clusters.

Extreme environments have also been investigated by researchers in the hope that Streptomyces from these areas would express a different repertoire of antibiotics. In Russia, researchers have been investigating the guts of amphipods inhabiting the bottom of Lake Baikal, where temperatures are rarely above $4{ }^{\circ} \mathrm{C}$. They have isolated many Streptomyces strains that produce a new series of antibiotics effective against Gram-positive and Gram-negative bacteria $[62,63]$.

\section{Co-cultivation}

It is quite typical to find multiple species of Streptomyces in traditional medical preparations such as soil or moonmilk $[50,54,64]$. Now, it has been discovered that competition and collaboration between Streptomyces and other species can also awaken silent antibiotic-synthesis clusters [65]. It has even been reported that the addition of Streptomyces that do not produce antibiotics can increase the antimicrobial potential of other antibiotic-producing Streptomyces through production of enhancement compounds like cyslabdan [66]. Although cyslabdan (known as a potentiator) has very little antimicrobial activity itself, it can enhance the antibiotic activity of $\beta$-lactams 1000 -fold by inhibiting peptidoglycan synthesis in MRSA [66]. As a quicker route than co-culture, some researchers have been adding extracts of bacterial competitors or sub-inhibitory doses of antibiotics to elicit the production of antibiotics by silent gene clusters [58]. As discussed earlier, antibacterial resistance in Streptomyces is closely linked to antibacterial production [67].

\section{Multiple antibiotic therapy}

Many traditional medicines contain a mixture of Streptomyces producing several antibiotics. This is a good strategy to reduce the possibility of resistance evolving quickly. The idea of using multiple antibiotics as a treatment option has become more widespread in the treatment of multi-resistant organisms and immunocompromised patients. The case of TB is one such example. Resistant TB strains started to appear not long after the introduction of streptomycin and isoniazid. The solution to this was to use an approach known as combination therapy. This is usually a combination of four second-line drugs (including amikacin, kanamycin, capreomycin and linezolid) with the addition of pyrazinamide over a period of 18-24 months. To add to this, two new anti-TB drugs, delamanid and bedaquiline, have also been approved for the first time in 50 years $[68,69]$.

\section{Media stimulation of antibiotic production from Streptomyces}

The nutritional conditions under which Streptomyces are cultivated affects their antibiotic production. Many traditional medicines are applied in their raw state, usually incorporating some of the original isolation material, which can be chemically quite complex. Typical laboratory Streptomyces cultivation media contains a combination of yeast extract, complex starches, mannitol or some other sugar, humic acids on some occasions and perhaps supplementary minerals. These ingredients form the basis for the standard International Streptomyces project agars (ISP) 1-7 [70]. However, without some of the micronutrients or complex chemicals present in their original growth environments, some environmental antibiotic producers may lose their potency (antimicrobial production). To counteract this decline, recent innovations have seen researchers incorporate some native (isolation) material in 
their media, for instance soil that contains rare earth metals. These have been reported to stimulate some strains of Streptomyces to increase their antimicrobial production by 12 -fold $[71,72]$. Alternatively, other researchers have dispensed with intricate media formulations and tried to cultivate antibioticproducing organisms in situ [73].

\section{CONCLUSION}

Due to the increase in multi-resistant pathogens and the dwindling number of new products being approved for the health market, there is an urgent need to find new sources of antibiotics. In the last 80 years, Streptomyces has made a massive contribution to the field of medicine, not only through antibacterial antibiotics, but also through antifungal, antiparasitic and anticancer compounds. Recent isolations of Streptomyces from traditional medicine suggest that these bacteria have played an integral role in human health for longer than previously thought. This new source of Streptomyces can also help to replenish the much-depleted reservoir of emergency antibiotics to combat multi-resistant pathogens and perhaps provide the much-needed structural diversity needed for a new generation of novel antibiotics. Moreover, knowledge of their traditional use is more than a mere historical curiosity, as they could help us to unlock important factors in the complex production and/or application of antibiotics. Finally, to ensure the continued availability of this resource, it is imperative that the habitats and microbial genera associated with these Streptomyces are conserved, and that accurate information and data related to their prevalence, properties and characteristics are extensively documented.

\section{Funding information}

This work received no specific grant from any funding agency.

\section{Acknowledgements}

We acknowledge the help of Dr Dušica Vujaklija, who took time to read over this article and make helpful suggestions.

\section{Conflicts of interest}

The authors declare that there are no conflicts of interest

\section{References}

1. de Lima Procópio RE, da Silva IR, Martins MK, de Azevedo JL, de Araújo JM. Antibiotics produced by Streptomyces. Braz J Infect Dis 2012;16:466-471.

2. Waksman SA, Schatz A, Reynolds DM. Production of antibiotic substances by actinomycetes. Ann N Y Acad Sci 2010;1213:112-124.

3. Sarmiento-Vizcaíno A, Espadas J, Martín J, Braña AF, Reyes F et al. Atmospheric precipitations, hailstone and rainwater, as a novel source of Streptomyces producing bioactive natural products. Front Microbiol 2018:9:773.

4. Ribeiro da Cunha B, Fonseca LP, Calado CRC. Antibiotic discovery: where have we come from, where do we go? Antibiotics 2019;8:45.

5. Chater KF. Streptomyces inside-out: a new perspective on the bacteria that provide us with antibiotics. Philos Trans $R$ Soc Lond $B$ Biol Sci 2006;361:761-768.

6. McDonald BR, Currie CR. Lateral gene transfer dynamics in the ancient bacterial genus Streptomyces. mBio 2017;8:e00644-17.

7. Chater KF. Recent advances in understanding Streptomyces. F1000Res 2016;5:2795.
8. Bibb MJ. Regulation of secondary metabolism in streptomycetes. Curr Opin Microbiol 2005;8:208-215.

9. Wainwright M. Streptomycin: discovery and resultant controversy. Hist Philos Life Sci 1991;13:97-124.

10. Mistiaen V. Time, and the great healer. The Guardian, 2 November 2002. https://www.theguardian.com/education/2002/nov/02/ research.highereducationhttps://www.theguardian.com/education/2002/nov/02/research.highereducation.

11. Waksman SA, Schatz A. Soil enrichment and development of antagonistic microorganisms. J Bacteriol 1946;51:305-316.

12. Schatz A, Bugle E, Waksman SA. Streptomycin, a substance exhibiting antibiotic activity against Gram-positive and Gram-negative bacteria. Proc Soc Exp Biol Med 1944;55:66-69.

13. Martens E, Demain AL. Platensimycin and platencin: promising antibiotics for future application in human medicine. J Antibiot 2011;64:705-710.

14. Wang J, Soisson SM, Young K, Shoop W, Kodali S et al. Platensimycin is a selective FabF inhibitor with potent antibiotic properties. Nature 2006;441:358-361.

15. Davies J. Where have all the antibiotics gone? Can J Infect Dis Med Microbiol 2006;17:287-290.

16. Nakaew N, Lumyong S, Sloan WT, Sungthong R. Bioactivities and genome insights of a thermotolerant antibiotics-producing Streptomyces sp. TM32 reveal its potentials for novel drug discovery. Microbiologyopen 2019;8:e842.

17. Landman $\mathrm{OE}$, Burchard W. The mechanism of action of streptomycin as revealed by normal and abnormal division in streptomycin-dependent salmonellae. Proc Natl Acad Sci USA 1962;48:219-228.

18. Kapoor G, Saigal S, Elongavan A. Action and resistance mechanisms of antibiotics: a guide for clinicians. J Anaesthesiol Clin Pharmacol 2017:33:300-305.

19. Taylor SD, Palmer M. The action mechanism of daptomycin. Bioorg Med Chem 2016:24:6253-6268.

20. Felnagle EA, Jackson EE, Chan YA, Podevels AM, Berti AD et al. Nonribosomal peptide synthetases involved in the production of medically relevant natural products. Mol Pharm 2008:5:191-211.

21. Risdian C, Mozef T, Wink J. Biosynthesis of polyketides in Streptomyces. Microorganisms 2019;7:124.

22. Falkinham JO, Wall TE, Tanner JR, Tawaha K, Alali FQ et al. Proliferation of antibiotic-producing bacteria and concomitant antibiotic production as the basis for the antibiotic activity of Jordan's red soils. Appl Environ Microbiol 2009;75:2735-2741.

23. Nelson ML, Dinardo A, Hochberg J, Armelagos GJ. Brief communication: mass spectroscopic characterization of tetracycline in the skeletal remains of an ancient population from Sudanese Nubia 350-550 CE. Am J Phys Anthropol 2010;143:151-154.

24. Roberts MJD. The politics of professionalization: MPs, medical men, and the 1858 Medical Act. Med Hist 2009:53:37-56.

25. Fleming $A$. On the antibacterial action of cultures of a penicillium, with special reference to their use in the isolation of $B$. influenzæ. Br J Exp Pathol 1929:10:226-236.

26. Cordell GA, Farnsworth NR, Beecher CWW, Doel Soejarto D, Kinghorn $A D$ et al. Novel strategies for the discovery of plant-derived anticancer agents. In: Anticancer Drug Discovery and Development: Natural Products and New Molecular Models. Developments in Oncology. Boston, MA: Springer; 1994.

27. Wardecki T, Brotz E, De Ford C, von Loewenich FD, Rebets Y et al. Endophytic Streptomyces in the traditional medicinal plant Arnica montana L.: secondary metabolites and biological activity. Antonie Van Leeuwenhoek 2015;108:391-402.

28. Oberhofer M, Hess J, Leutgeb M, Gössnitzer F, Rattei T et al. Exploring actinobacteria associated with rhizosphere and endosphere of the native alpine medicinal plant Leontopodium nivale subspecies alpinum. Front Microbiol 2019;10:2531. 
29. Nalini MS, Prakash HS. Diversity and bioprospecting of actinomycete endophytes from the medicinal plants. Lett Appl Microbiol 2017:64:261-270

30. Zhao H, Yang A, Zhang N, Li S, Yuan T et al. Insecticidal endostemonines A-J produced by endophytic Streptomyces from Stemona sessilifolia. J Agric Food Chem 2020;68:1588-1595.

31. Liu M, Abdel-Mageed WM, Ren B, He W, Huang $P$ et al. Endophytic Streptomyces sp. Y3111 from traditional Chinese medicine produced antitubercular pluramycins. Appl Microbiol Biotechnol 2014:98:1077-1085

32. Colombo ME, Kunova A, Cortesi P, Saracchi M, Pasquali M. Critical assessment of Streptomyces spp. able to control toxigenic Fusaria in cereals: a literature and patent review. Int J Mol Sci 2019;20:6119

33. Qin S, Li J, Chen H-H, Zhao G-Z, Zhu W-Y et al. Isolation, diversity, and antimicrobial activity of rare actinobacteria from medicinal plants of tropical rain forests in Xishuangbanna, China. Appl Environ Microbiol 2009:75:6176.

34. Chakravorty J, Ghosh S, Meyer-Rochow V. Practices of entomophagy and entomotherapy by members of the Nyishi and Galo tribes, two ethnic groups of the state of Arunachal Pradesh (North-East India). J Ethnobiol Ethnomed 2011;7:5

35. Liu C, Han C, Jiang S, Zhao X, Tian Y et al. Streptomyces lasii sp. nov., a novel actinomycete with antifungal activity isolated from the head of an ant (Lasius flavus). Curr Microbiol 2018;75:353-358.

36. Chevrette MG, Carlson CM, Ortega HE, Thomas C, Ananiev GE et al. The antimicrobial potential of Streptomyces from insect microbiomes. Nat Commun 2019:10:516.

37. Seabrooks L, Hu L. Insects: an underrepresented resource for the discovery of biologically active natural products. Acta Pharm $\operatorname{Sin} B$ 2017:7:409-426

38. Qin Z, Munnoch JT, Devine R, Holmes NA, Seipke RF et al. Formicamycins, antibacterial polyketides produced by Streptomyces formicae isolated from African Tetraponera plant-ants. Chem Sci 2017:8:3218-3227.

39. Currie CR, Scott JA, Summerbell RC, Malloch D. Fungus-growing ants use antibiotic-producing bacteria to control garden parasites. Nature 1999:398:701-704

40. Poulsen M, Cafaro MJ, Erhardt DP, Little AEF, Gerardo NM et al. Variation in Pseudonocardia antibiotic defence helps govern parasite-induced morbidity in Acromyrmex leaf-cutting ants. Environ Microbiol Rep 2010;2:534-540.

41. Poulsen M, D-C Oh, Clardy J, Currie CR. Chemical analyses of wasp-associated Streptomyces bacteria reveal a prolific potential for natural products discovery. PloS One 2011;6:e16763.

42. Müller WEG, Batel R, Schröder HC, Müller IM. Traditional and modern biomedical Prospecting: part I - the history: sustainable exploitation of biodiversity (sponges and invertebrates) in the Adriatic Sea in Rovinj (Croatia). Evid Based Complement Altern Med 2004:1:71-82.

43. Pronzato $\mathrm{R}$, Manconi R. Mediterranean commercial sponges: over 5000 years of natural history and cultural heritage. Mar Ecol 2008;29:146-166.

44. Shaik M, Girija Sankar G, Iswarya M, Rajitha P. Isolation and characterization of bioactive metabolites producing marine Streptomyces parvulus strain sankarensis-A10. J Genet Eng Biotechnol 2017:15:87-94.

45. Huang $X$, Kong $F$, Zhou S, Huang D, Zheng J et al. Streptomyces tirandamycinicus sp. nov., a Novel Marine Sponge-Derived Actinobacterium With Antibacterial Potential Against Streptococcus agalactiae. Front Microbiol 2019;10:482.

46. Cao DD, Trinh TTV, Mai HDT, Vu VN, Le HM et al. Antimicrobial lavandulylated flavonoids from a sponge-derived Streptomyces sp. G248 in East Vietnam Sea. Mar Drugs 2019:17:529

47. Balasubramanian S, Skaf J, Holzgrabe U, Bharti R, Förstner KU et al. A new bioactive compound from the marine sponge-derived Streptomyces sp. SBT348 inhibits Staphylococcal growth and biofilm formation. Front Microbiol 2018:9:1473.
48. Gosse JT, Ghosh S, Sproule A, Overy D, Cheeptham N et al. Whole genome sequencing and metabolomic study of cave Streptomyces isolates ICC1 and ICC4. Front Microbiol 2019:10:1020.

49. Rangseekaew P, Pathom-aree W. Cave actinobacteria as producers of bioactive metabolites. Front Microbiol 2019:10:387.

50. Maciejewska M, Adam D, Martinet L, Naome A, Calusinska M et al. A phenotypic and genotypic analysis of the antimicrobial potential of cultivable Streptomyces isolated from cave moonmilk deposits. Front Microbiol 2016;7:1455.

51. Hamedi J, Kafshnouchi M, Ranjbaran M. A study on actinobacterial diversity of Hampoeil cave and screening of their biological activities. Saudi J Biol Sci 2019:26:1587-1595.

52. Behroozian S, Svensson SL, Davies J. Kisameet clay exhibits potent antibacterial activity against the ESKAPE pathogens. mBio 2016;7:e01842-15.

53. Terra L, Dyson PJ, Hitchings MD, Thomas L, Abdelhameed A et al. A novel alkaliphilic Streptomyces inhibits ESKAPE pathogens. Front Microbiol 2018:9:2458.

54. Svensson SL, Behroozian S, Xu W, Surette MG, Li L et al. Kisameet glacial clay: an unexpected source of bacterial diversity. mBio 2017:8:e00590-17.

55. Bentley SD, Chater KF, Cerdeño-Tárraga A-M, Challis GL, Thomson NR et al. Complete genome sequence of the model actinomycete Streptomyces coelicolor A3(2). Nature 2002;417:141-147.

56. Chiang Y-M, Chang S-L, Oakley BR, Wang CCC. Recent advances in awakening silent biosynthetic gene clusters and linking orphan clusters to natural products in microorganisms. Curr Opin Chem Biol 2011:15:137-143.

57. Reen FJ, Romano S, Dobson ADW, O'Gara F. The sound of silence: activating silent biosynthetic gene clusters in marine microorganisms. Mar Drugs 2015;13:4754-4783.

58. Okada BK, Seyedsayamdost MR. Antibiotic dialogues: induction of silent biosynthetic gene clusters by exogenous small molecules. FEMS Microbiol Rev 2017;41:19-33.

59. Baral B, Akhgari A, Metsä-Ketelä M. Activation of microbial secondary metabolic pathways: avenues and challenges. Synth Syst Biotechnol 2018:3:163-178.

60. Romano S, Jackson SA, Patry S, Dobson ADW. Extending the 'One Strain Many Compounds' (OSMAC) principle to marine microorganisms. Mar Drugs 2018;16:244.

61. Sivalingam P, Hong K, Pote J, Prabakar K. Extreme environment Streptomyces: potential sources for new antibacterial and anticancer drug leads? Int J Microbiol 2019;2019:5283948.

62. Shishlyannikova TA, Kuzmin AV, Fedorova GA, Shishlyannikov SM, Lipko IA et al. Ionofore antibiotic polynactin produced by Streptomyces sp. 156A isolated from Lake Baikal. Nat Prod Res 2017:31:639-644

63. Terkina IA, Parfenova VV, Ahn TS. Antagonistic activity of actinomycetes of Lake Baikal. Appl Biochem Microbiol 2006:42:173-176.

64. Conti R, Chagas FO, Caraballo-Rodriguez AM, da Paixão Melo WG, do Nascimento AM et al. Endophytic actinobacteria from the Brazilian medicinal plant Lychnophora ericoides Mart. and the biological potential of their secondary metabolites. Chem Biodivers 2016;13:727-736

65. Challis GL, Hopwood DA. Synergy and contingency as driving forces for the evolution of multiple secondary metabolite production by Streptomyces species. Proc Natl Acad Sci USA 2003;100 (Suppl. 2):14555-14561.

66. Fukumoto A, Kim Y-P, Matsumoto A, Takahashi Y, Shiomi K et al. Cyslabdan, a new potentiator of imipenem activity against methicillin-resistant Staphylococcus aureus, produced by Streptomyces sp. K04-0144. J Antibiot 2008;61:7-10.

67. Nodwell JR. Novel links between antibiotic resistance and antibiotic production. J Bacteriol 2007:189:3683-3685.

68. Park M, Satta G, Kon OM. An update on multidrug-resistant tuberculosis. Clin Med 2019;19:135-139. 
69. Rabahi MF, da Silva Júnior JLR, Ferreira ACG, TannusSilva DGS, Conde MB. Tuberculosis treatment. J Bras Pneumol 2017;:43:472-486

70. Jiang Y. Isolation and cultivation methods of Actinobacteria. In: Li Q (ed). Actinobacteria. Rijeka: IntechOpen; 2016.

71. Kawai K, Wang G, Okamoto S, Ochi K. The rare earth, scandium, causes antibiotic overproduction in Streptomyces spp. FEMS Microbiol Lett 2007;274:311-315.

72. Tanaka Y, Hosaka T, Ochi K. Rare earth elements activate the secondary metabolite-biosynthetic gene clusters in Streptomyces coelicolor A3(2). J Antibiot 2010;63:477-481.

73. Nichols D, Cahoon N, Trakhtenberg EM, Pham L, Mehta A et al. Use of ichip for high-throughput in situ cultivation of 'uncultivable' microbial species. Appl Environ Microbiol 2010;76:2445-2450.

74. Seto H, Imai S, Tsuruoka T, Ogawa H, Satoh A et al. Studies on the biosynthesis of bialaphos (SF-1293) part 3. Production of phosphinic acid derivatives, MP-103, MP-104 and MP-105, by a blocked mutant of Streptomyces hygroscopicus SF-1293 and their roles in the biosynthesis of bialaphos. Biochem Biophys Res Commun 1983;111:1008-1014.

75. Kong J, Yi L, Xiong Y, Huang $Y$, Yang $D$ et al. The discovery and development of microbial bleomycin analogues. Appl Microbiol Biotechnol 2018;102:6791-6798.

76. Brock TD. Chloramphenicol. Bacteriol Rev 1961;25:32-48.

77. Miyairi N, Takashima M, Shimizu K, Sakai H. Studies on new antibiotics, cineromycins A and B. J Antibiot 1966;19:56-62.

78. Higgens CE, Kastner RE. Streptomyces clavuligerus sp. nov., a $\beta$-lactam antibiotic producer. Int J Syst Evol Microbiol 1971:21:326-331.

79. MacLeod AJ, Ross HB, Ozere RL, Digout G, Van Rooyen CE. Lincomycin: a new antibiotic active against staphylococci and other Gram-positive cocci: clinical and laboratory studies. Can Med Assoc J 1964:91:1056-1060.

80. Eliopoulos GM, Willey S, Reiszner E, Spitzer PG, Caputo G et al. In vitro and in vivo activity of LY 146032, a new cyclic lipopeptide antibiotic. Antimicrob Agents Chemother 1986;30:532-535.

81. Washington JA II, Wilson WR. Erythromycin: a microbial and clinical perspective after 30 years of clinical use (second of two parts)*. Mayo Clin Proc 1985;60:271-278.

82. Matthews PC, Barrett LK, Warren S, Stoesser N, Snelling M et al. Oral fosfomycin for treatment of urinary tract infection: a retrospective cohort study. BMC Infect Dis 2016;16:556.
83. Ottesen EA, Campbell WC. Ivermectin in human medicine. J Antimicrob Chemother 1994;34:195-203.

84. Umezawa H. Kanamycin: its discovery. Ann N Y Acad Sci 1958;76:20-26.

85. Waksman SA, Lechevalier HA. Neomycin, a new antibiotic active against streptomycin-resistant bacteria, including tuberculosis organisms. Science 1949;109:305-307.

86. Hazen EL, Brown R. Two antifungal agents produced by a soil actinomycete. Science 1950;112:423.

87. Sehgal SN. Sirolimus: its discovery, biological properties, and mechanism of action. Transplant Proc 2003;35:S7-S14.

88. Arai T, Takahashi K, Ishiguro K, Mikami Y. Some chemotherapeutic properties of two new antitumor antibiotics, saframycins A and C. Gan 1980;71:790-796.

89. Petković H, Cullum J, Hranueli D, Hunter IS, Perić-Concha N et al. Genetics of Streptomyces rimosus, the oxytetracycline producer. Microbiol Mol Biol Rev 2006;70:704-728.

90. Geraci JE, Heilman FR, Nichols DR, Ross GT, Wellman WE. Some laboratory and clinical experiences with a new antibiotic, vancomycin. Proc Staff Meet Mayo Clin 1956;31:564-582.

91. NC-IUBMB. Tetracycline Biosynthesis (accessed 4 March 2020). https://www.qmul.ac.uk/sbcs/iubmb/enzyme/reaction/phenol/ tetracycline.html

92. Galea CA, Han M, Zhu Y, Roberts K, Wang J et al. Characterization of the polymyxin $\mathrm{D}$ synthetase biosynthetic cluster and product profile of Paenibacillus polymyxa ATCC 10401. J Nat Prod 2017:80:1264-1274.

93. Yang $X$, Yang $Y$, Peng T, Yang F, Zhou $\mathrm{H}$ et al. A new cyclopeptide from endophytic Streptomyces sp. YIM 64018. Nat Prod Commun 2013:8:1753-1754.

94. Shi Y, Zhang $X$, Lou K. Isolation, characterization, and insecticidal activity of an endophyte of drunken horse grass, Achnatherum inebrians. J Insect Sci 2013;13:151:1-12.

95. Khieu T-N, Liu M-J, Nimaichand S, Quach N-T, Chu-Ky S et al. Characterization and evaluation of antimicrobial and cytotoxic effects of Streptomyces sp. HUST012 isolated from medicinal plant Dracaena cochinchinensis Lour. Front Microbiol 2015;6:574.

96. Gos F, Savi DC, Shaaban KA, Thorson JS, Aluizio R et al. Antibacterial activity of endophytic actinomycetes isolated from the medicinal plant Vochysia divergens (Pantanal, Brazil). Front Microbiol 2017:8:1642.

\section{Five reasons to publish your next article with a Microbiology Society journal}

1. The Microbiology Society is a not-for-profit organization.

2. We offer fast and rigorous peer review - average time to first decision is 4-6 weeks.

3. Our journals have a global readership with subscriptions held in research institutions around the world.

4. $80 \%$ of our authors rate our submission process as 'excellent' or 'very good'.

5. Your article will be published on an interactive journal platform with advanced metrics

Find out more and submit your article at microbiologyresearch.org. 